\title{
Controlled-Temperature Studies of Growth, Enzymology, and Sucrose Production by Two Sugarcane Varieties in Puerto Rico
}

\author{
Alex G. Alexander and George Samuels ${ }^{1}$
}

\section{INTRODUCTION}

Although scientists have known for years that temperature profoundly affects the growth and sugar production of cane, temperature has not been measured as a precisely controlled variable until recent times. Even today the mechanisms of temperature action are almost totally obscure.

Workers in Puerto Rico and elsewhere have noted climatic factors which alter sucrose production. Lugo López and Capó (33), ${ }^{2}$ after extensive analysis of Puerto Rico field data, reported that cool nights with relatively broad ranges between maximum and mimimum temperatures favored high sucrose yields. Samuels (38) has described cool temperature as a major factor in ripening sugarcane. In Puerto Rico rising temperatures plus rainfall often cause decline in percent-recoverable sugar during May and June.

Over the past 5 years progress has been made toward delineating specific physiological and biochemical effects of temperature on sugarcane. Workers in Hawaii suggested that temperature may affect flowering stimuli during the period of floral differentiation (23). Robinson (36), in Australia, reported delayed growth action of gibberellic acid when the chemical was applied during low-temperature periods of early winter. Phytotron facilities at the David North Plant Research Centre are being utilized for precise climate control in physiological and biochemical studies of cane. ${ }^{3}$ Hatch and Glasziou (30), after exposing 3-month-old sugarcane to combinations of five temperatures and three water regimes, found that the acid-invertase content of immature storage tissue changed by a factor of up to tenfold in 10 days. The acid-invertase content was linearly related to the elongation rate of immature internodes, both increasing with increasing temperature in the presence of adequate water.

In Puerto Rico, temperature effects on numerous enzymes related to sucrose production have been studied in vitro. These include starch phosphorylase (8), the Q-enzyme or polysaccharide-branching factor (10), acid invertases (12), amylase (13), acid phosphatases (11), peroxidase (14), tyrosinase (15), and cytochrome $\mathrm{C}$ oxidase (16). Temperature under-

1 Plant Physiologist and Agronomist, Agricultural Experiment Station, Mayagüez Campus, University of Puerto Rico, Río Piedras, P.R.

2 Italic numbers in parentheses refer to Literature Cited, pp. 216-7.

a Personal communication with Dr. P. Robinson, C. S. R., Australia. 
standably has a profound effect upon cane enzymes. In general, maximum activity is acheived at around $37^{\circ} \mathrm{C}$., although amylase is highly active at $50^{\circ} \mathrm{C}$., and cane peroxidase regenerates activity after total inactivation by boiling for 5 minutes.

Controlled-climate facilities were recently completed at Rio Piedras, Puerto Rico. These are designed to provide a broad range of temperature, humidity and light variables which can be controlled for investigations with numerous plant species. The present paper summarizes initial controlled-climate studies with sugarcane. Our objective was to evaluate growth, enzymology, and sugar production of two varieties maintained under continually high and low temperatures.

\section{MATERIALS AND METHODS}

Two varieties were grown by sand culture in an ordinary greenhouse for 12 weeks prior to treatment. One-eye cuttings of P.R. 980 and P.R. 1059 were planted in $\mathrm{HCl}$-washed quartz sand contained in glazed 2-gallon pots. Each container received 1 liter of complete nutrient solution daily for the duration of the study. ${ }^{4}$ About 1 liter of tapwater was also given daily. At 12 weeks, uniform plants free of disease and insects were transferred to the phytotron. A total of 16 pots comprised the initial experiment including four replicates of each of two temperature and two variety treatments.

Two walk-in chambers were employed. Both have floor dimensions of $111 / 2 \times 171 / 2$ feet, and a minimum roof elevation of $81 / 2$ feet. Each room has a sloping glass roof in the nature of an ordinary greenhouse. Sufficient sunlight passes for normal plant growth and development. Every chamber is served by an independent air-conditioning unit located at the rear of the phytotron. This unit is designed to maintain air temperature and humidity at predetermined levels. Conditioned air flows beneath the building, enters the respective chamber from each side near the floor level, and passes back to the conditioning unit via overhead outlets. Air turbulance is reduced by a series of baffles at the inlets. Plants are shifted within the chambers on elevated mobile platforms. These facilitate easy movement in a daily rotation sequence.

Treatment levels were originally planned for $55^{\circ}$ and $80^{\circ} \mathrm{F}$. However, small readjustments were required for the air-conditioning equipment so that precision of no more than 55 to $60^{\circ}$ and 80 to $85^{\circ} \mathrm{F}$. can be claimed. Malfunction of equipment once permitted temperatures to reach $95^{\circ} \mathrm{F}$. in both chambers for a period of about 12 hours during the third week.

4 Nutrient concentrations, expressed as milliequivalents per liter, were provided as follows: Nitrate, 10; phosphate, 6; potassium, 5; calcium, 3; magnesium, 2; and sulfate, 2. Microelements, expressed as parts per million, were supplied as follows: Boron, 0.05 ; copper, 0.02 ; manganese, 0.50 ; zinc, 0.05 , molybdenum, 0.01 ; and iron, 1.0. 
Samples were taken for sugar and enzyme analyses after 10 weeks of treatment. Four plants from each replicate were cut at the surface of the sand and weighed. The basal 14 inches of leaves +1 to +4 were frozen in a mixture of Dry Ice and acetone. These were lyophilized and ground to a fine powder in accordance with procedures described previously (3). Millable cane was analyzed for Brix and polarization with the aid of a small roller-type laboratory mill.

Clarified water extracts of the plant powder were analyzed for total ketose by the method of Roe (\$7), and for sucrose by the modification of Cardini et al. (22). Fructose was estimated by subtracting sucrose values from those of total ketose. Protein was precipitated from water extracts at $\mathrm{pH} 7.0$ with solid ammonium sulfate as described earlier (3). The protein was taken up in a minimum of water or buffer, clarified by centrifuge, and

TABLE 1.-Mean fresh weights of 2 sugarcane varieties subjected to controlled cool and warm lemperatures ${ }^{1}$

\begin{tabular}{|c|c|c|c|}
\hline \multirow{2}{*}{ Variety } & \multicolumn{2}{|c|}{ Grams per plant at- } & \multirow{2}{*}{ Mean } \\
\hline & $55-60^{\circ} \mathrm{F}$. & $80-85^{\circ} \mathrm{F}$. & \\
\hline $\begin{array}{l}\text { P.R. } 980 \\
\text { P.R. } 1059\end{array}$ & $\begin{array}{l}175 \\
175\end{array}$ & $\begin{array}{l}322 \\
280\end{array}$ & $\begin{array}{l}249 \\
228\end{array}$ \\
\hline Mean & 175 & 301 & 239 \\
\hline
\end{tabular}

1 Each figure represents the computed mean of four replicates.

refrigerated without dialysis. Appropiate dilutions were employed for enzyme assay within 24 hours. Phosphatase and ATP-ase was measured by techniques described previously (11), as was amylase (13), invertase (12), peroxidase (14), and tyrosinase (15). Protein content of the enzyme preparations was determined by the method of Sutherland et al. (40), and enzyme action was recorded as specific activity (activity units per milligram of protein).

\section{RESULTS AND DISCUSSION}

\section{GROWTH AND TEMPERATURE RELATIONSHIPS}

Although plants were of uniform size and appearance when transferred to the phytotron, growth changes were visible within about 10 days. Water requirement in the warm chamber was vastly increased. Cool temperature permitted relatively slow growth as evidenced by fresh weights recorded in table 1. The latter plants remained quite stocky and toward the close of the study exhibited visual leaf symptoms similar to those of phosphorus 
and potassium deficiencies. Growth appeared to be excessive in the warm chamber where a spindly condition appeared in all plants and lodging was frequent among P.R. 980. Insect and disease infestations were far more prevalent in the warm environment.

In commercial cane fields P.R. 980 outyields P.R. 1059 in cane tonnage production. This capacity for growth was demonstrated in the warm

TABLE 2.-Sugar content of leaf and immature storage tissues from sugarcane subjected to controlled cool and warm temperatures ${ }^{1}$

\begin{tabular}{|c|c|c|c|c|c|}
\hline \multirow{2}{*}{ Variety } & \multirow{2}{*}{ Temperature $\left({ }^{\circ} \mathrm{F}.\right)$} & \multicolumn{3}{|c|}{ Leaf (mg./g. of dry weight) of total- } & \multirow{2}{*}{ Mean } \\
\hline & & Ketose & Sucrose & Fructose & \\
\hline \multirow[t]{2}{*}{ P.R. 980} & $\begin{array}{l}55-60 \\
80-85\end{array}$ & $\begin{array}{l}46.2 \\
69.5\end{array}$ & $\begin{array}{l}23.8 \\
62.8\end{array}$ & $\begin{array}{r}22.4 \\
6.8\end{array}$ & $\begin{array}{l}30.8 \\
46.4\end{array}$ \\
\hline & Mean & 57.9 & 43.3 & 14.5 & 38.6 \\
\hline \multirow[t]{2}{*}{ P.R. 1059} & $\begin{array}{l}55-60 \\
80-85\end{array}$ & $\begin{array}{l}73.8 \\
89.3\end{array}$ & $\begin{array}{l}48.3 \\
85.3\end{array}$ & $\begin{array}{r}25.5 \\
4.0\end{array}$ & $\begin{array}{l}49.2 \\
59.5\end{array}$ \\
\hline & Mean & 81.6 & 66.8 & 14.8 & 54.4 \\
\hline
\end{tabular}

Immature storage tissue (mg./g. of dry weight)-

\begin{tabular}{l|r|r|r|r|r}
\hline P.R. 980 & \multicolumn{1}{|c|}{$\begin{array}{l}55-60 \\
80-85\end{array}$} & $\begin{array}{l}257 \\
249\end{array}$ & $\begin{array}{l}50.0 \\
41.0\end{array}$ & $\begin{array}{l}207 \\
208\end{array}$ & $\begin{array}{l}171 \\
166\end{array}$ \\
\cline { 2 - 3 } & Mean & 253 & 45.5 & 208 & 169 \\
\hline P.R. 1059 & $55-60$ & 273 & 90.0 & 183 & 182 \\
& $80-85$ & 260 & 40.0 & 221 & 174 \\
\cline { 2 - 4 } & Mean & 267 & 65.0 & 202 & 178 \\
\hline
\end{tabular}

1 Each figure represents the computed mean of 4 replicates.

chamber where temperatures ranged near those of the normal Puerto Rico climate. However, cool temperature retarded growth of both varieties, and the vigor of P.R. 980 over P.R. 1059 was no longer evident under cold conditions.

\section{SUGAR RESPONSES TO TEMPERATURE AND VARIETY}

Both temperature and variety treatments caused sugar changes of considerable magnitude (table 2). Leaf sucrose was far higher in warm temperatures, regardless of variety. This warm-temperature effect was most 
pronounced in P.R. 980 where leaf-sucrose content was more than double that obtained by the cool treatment. At both temperatures P.R. 1059 was superior to P.R. 980 as a sucrose producer.

Increased sucrose at 80 to $85^{\circ} \mathrm{F}$. clearly reflects a higher total ketose production. Nevertheless, the predominance of leaf fructose among "cool" plants suggests a more rapid sucrose inversion at low temperature, or a greater fructose utilization at high temperature. The latter possibility presupposes ketose phosphorylation via a fructokinase, followed by a strong isomerase reaction:

$$
\text { Fructose-6-phosphate } \rightleftharpoons \text { Glucose-6-phosphate }
$$

An isomerase has been extracted from cane leaf tissues but efforts to detect a fructokinase were unsuccessful ( $(3)$.

TABLE 3.-Comparison of growth, Brix, and polarization values for \& sugarcane varities subjected to controlled cool and warm temperatures

\begin{tabular}{c|c|c|c|c}
\hline \multirow{2}{*}{ Variety } & Temperature ( ${ }^{\circ}$ F.) & \multicolumn{3}{|c}{ Mean values for- } \\
\cline { 2 - 4 } & & Brix & Polarization & Growth $^{2}$ \\
\hline P.R. 980 & $55-60$ & 14.2 & 50.0 & 175 \\
& $80-85$ & 9.4 & 20.6 & 322 \\
\cline { 2 - 5 } & Mean & 11.8 & 35.4 & 248 \\
\hline P.R. 1059 & $55-60$ & 15.0 & 49.4 & 175 \\
& $80-85$ & 13.7 & 44.1 & 280 \\
\cline { 2 - 4 } & Mean & 14.3 & 46.8 & 228 \\
\hline
\end{tabular}

1 Grams of fresh weight per plant.

Sugar values for immature storage tissue disclosed a striking varietal effect (table 2). Although leaf sucrose production was highest at 80 to $85^{\circ} \mathrm{F}$, neither variety was able to accumulate high sucrose in storage tissue under warm conditions. However, P.R. 1059 clearly succeeded in accumulating sucrose at 55 to $60^{\circ}$ F. Thus, P.R. 1059 not only appeared to be a better sucrose producer, but it also utilized the cold stimulus more effectively for sugar accumulation in young storage tissues.

Brix and polarization data also stress varietal differences in response to variable temperature (table 3). In millable cane, P.R. 980 responded far more readily to the cold stimulus than did P.R. 1059. Under field conditions P.R. 980 is a heavy tonnage producer, but fails to yield sucrose at high rates characteristic of P.R. 1059. The Brix and polarization data suggest that P.R. 980 needs a cold stimulus to accumulate maximum su- 
crose, whereas the cool exposure is not as essential for P.R. 1059. The latter variety can accumulate sucrose nearly as well at high temperature and also increase its rate of growth.

It has been proposed that rapid sugar accumulation in sugar beet and cane following a series of cold nights is attributable to faster translocation at lower temperatures (41). Other workers suggest that failure of plants to store sugars at high temperatures is primarily due to sugar utilization for growth (30). The latter thesis agrees well with our own data, except that variety appears to determine the degree of sensitivity to cold treat. ment. An important point for future exploration is the precise temperature, or duration of cool exposure, required by varieties such as P.R. 980 for the cold stimulus to be effective.

\section{ENZYME RESPONSES TO VARIETY AND TEMPERATURE}

Numerous enzyme variations were observed with the leaf and meristem preparations (table 4). By far the greatest differences were found in leaves, where varietal effects outweighed those of temperature. It must be remembered that these values reflect enzyme content rather than in vivo activity, since all enzymes were measured at constant temperature in the laboratory. Each of the five leaf enzymes assayed was less active in P.R. 980 than in P.R. 1059. Temperature effects were evident with the leaf enzymes ATP-ase, amylase, and peroxidase. Meristem enzymes showed little varietal variations other than that recorded for invertase. Also characteristic of meristem preparations was a general suppression of phosphatase, ATP-ase, amylase, invertase, and peroxidase by the cool temperature.

\section{ENZYMOLOGY RELATED TO GROWTH AND SUGAR PRODUCTION}

From among the myriad of enzyme changes an investigator might understandably seek answers to two major questions: 1, Why does P.R. 980 consistently lag behind P.R. 1059 in sugar production, although it makes excellent growth? 2, Why are the sugar storage responses to cold treatment at variance between the two varieties? Final answers may never be given for these questions, yet much is told to us by the enzyme data.

With regard to varietal sugar production one should analyze the leafenzyme data in table 4. We know that, regardless of temperature, P.R. 980 could not form sucrose as readily as P.R. 1059, and we see in table 4 that P.R. 980 also failed to maintain enzyme activity comparable to that of P.R. 1059. On finding an apparent suppression of such catalysts as phosphatase, ATP-ase, amylase, and peroxidase, our immediate impression is that P.R. 980 should be the best sugar producer. Indeed, suppression of these same catalysts has been found to be a characteristic of sucrose- 
promoting treatments $(3,7,9,19)$. However, further study of table 4 indicates that mean enzyme values for P.R. 980 are unusually low. Only leaf protein is high for P.R. 980, itself a suggestion that the plant is either experiencing high nitrogen uptake or is in some way prepared for rapid

TABLE 4.-Protein content and mean specific-activity values for enzymes of leaf and immature storage tissues from sugarcane subjected to controlled cool and

warm temperalures 1

\begin{tabular}{|c|c|c|c|c|c|c|c|c|c|}
\hline \multirow[b]{2}{*}{ Variety } & \multirow[b]{2}{*}{$\begin{array}{c}\text { Temperature } \\
\left({ }^{\circ} \mathrm{F} .\right)\end{array}$} & \multicolumn{7}{|c|}{ Results for leaf tissues- } & \multirow{2}{*}{ Mean } \\
\hline & & $\begin{array}{l}\text { Phos- } \\
\text { phatase }\end{array}$ & \multicolumn{2}{|c|}{ ATP-ase } & Amylase $\underset{\text { oxi }}{\mathrm{F}}$ & \begin{tabular}{l|} 
Per- \\
zidase
\end{tabular} & \begin{tabular}{c|c} 
Poly- \\
phenol \\
oxidase
\end{tabular} \mid $\mathbf{P}$ & Protein 2 & \\
\hline P.R. 980 & $\begin{array}{l}55-60 \\
80-85\end{array}$ & $\begin{array}{l}4.3 \\
6.5\end{array}$ & \multicolumn{2}{|c|}{$\begin{array}{l}7.0 \\
8.4\end{array}$} & $\begin{array}{l}26 \\
55\end{array}$ & $\begin{array}{l}21 \\
27\end{array}$ & $\begin{array}{r}9 \\
14\end{array}$ & $\begin{array}{l}9.2 \\
9.3\end{array}$ & $\begin{array}{l}14.7 \\
21.0\end{array}$ \\
\hline & Mean & 5.4 & \multicolumn{2}{|c|}{7.7} & 51 & 24 & 12 & 9.3 & 17.9 \\
\hline P.R. 1059 & $\begin{array}{l}55-60 \\
80-85\end{array}$ & $\begin{array}{r}11.0 \\
9.0\end{array}$ & \multicolumn{2}{|c|}{$\begin{array}{l}16.0 \\
11.6\end{array}$} & $\begin{array}{r}78 \\
165\end{array}$ & $\begin{array}{l}52 \\
34\end{array}$ & $\begin{array}{l}20 \\
20\end{array}$ & $\begin{array}{l}5.9 \\
6.1\end{array}$ & $\begin{array}{l}35.4 \\
47.9\end{array}$ \\
\hline & \multirow[t]{3}{*}{ Mean } & 10.0 & \multicolumn{2}{|c|}{13.8} & 122 & 43 & 20 & 6.0 & 41.7 \\
\hline & & \multicolumn{7}{|c|}{ Results for immature storage tissues- } & \multirow[b]{2}{*}{ Mean } \\
\hline & & $\begin{array}{c}\text { Phos- } \\
\text { phatase }\end{array}$ & $\underset{\text { ase }}{\text { ATP. }}$ & $\begin{array}{l}\text { Amy- } \\
\text { lase }\end{array}$ & Invertase & $=\begin{array}{c}\text { Perox- } \\
\text { idase }\end{array}$ & $\mid \begin{array}{c}\text { Poly- } \\
\text { phenol } \\
\text { oxidase }\end{array}$ & Protein & \\
\hline \multirow[t]{2}{*}{ P.R. 980} & $\begin{array}{l}55-60 \\
80-85\end{array}$ & $\begin{array}{l}13 \\
22\end{array}$ & $\begin{array}{l}16 \\
23\end{array}$ & $\begin{array}{l}52 \\
71\end{array}$ & $\begin{array}{l}6.1 \\
8.2\end{array}$ & $\begin{array}{l}15 \\
23\end{array}$ & $\begin{array}{l}16 \\
16\end{array}$ & $\begin{array}{l}20 \\
12\end{array}$ & $\begin{array}{l}19.7 \\
27.2\end{array}$ \\
\hline & Mean & 18 & 20 & 62 & 7.2 & 19 & 16 & 16 & 23.5 \\
\hline P.R. 1059 & $\begin{array}{l}55-60 \\
80-85\end{array}$ & $\begin{array}{l}15 \\
18\end{array}$ & $\begin{array}{l}20 \\
20\end{array}$ & $\begin{array}{l}66 \\
70\end{array}$ & $\begin{array}{l}0.9 \\
6.9\end{array}$ & $\begin{array}{l}22 \\
22\end{array}$ & $\begin{array}{l}15 \\
15\end{array}$ & $\begin{array}{l}13 \\
13\end{array}$ & $\begin{array}{l}23.2 \\
25.3\end{array}$ \\
\hline & Mean & 17 & 20 & 68 & 3.9 & 22 & 15 & 13 & 24.3 \\
\hline
\end{tabular}

1 Each figure represents the computed mean of 4 replicates.

2 Protein is expressed as milligrams per gram of dry weight.

growth (20). The relatively high leaf protein also suggests a poor ratio of catalytic to inert types. Thus the cold-treated P.R. 980 plants appeared to be suffering from a general enzyme deficiency. It is suggested that while P.R. 1059 had sufficient catalytic potential for both growth and sugar production, P.R. 980 had insufficient potential even for growth. Supporting this thesis is the fact that the warm treatment which enabled P.R. 
980 to exceed P.R. 1059 in growth likewise raised the P.R. 980 enzyme values, while most of those of P.R. 1059 remained about equal or declined in response to warm treatment. Such an enzyme deficiency in one of two varieties, both of which received equal and adequate nitrogen, should not be due to nitrogen or amino acid shortage, or even to an inability to synthesize protein. Quite possibly it occurs because of a malfunctioning temperature-sensitive control mechanism for synthesis of catalytic protein. The degree of sensitivity for such a control mechanism is presumably a varietal charcteristic.

Particular interest is taken in the vast differences in leaf amylase content (table 4). The enzyme's activity in P.R. 980 was only about one-third of that found in P.R. 1059. Within variety treatments, cool temperature lowered amylase values to about one-half of those obtained with warm temperature.

Although amylase is one of the most ancient of all known enzymes (39), its role in sugar-starch transformations, empirically established beyond reasonable doubt, remains obscure as to precise action and mechanism of control. For years amylase was regarded only as a hydrolizing catalyst of storage polysaccharides. Attempts to demonstrate starch synthesis by the reverse amylase reaction were invariably negative. However, early work with potato tubers led scientists to suspect a phosphorylase-coupled and temperature-controlled interconversion of starch and sugar (32). The equilibrium constant (Keq) of such a mechanism would be greatly influenced by amylase. Other workers stressed the roles of independent phosphorylases acting to form both sucrose (29) and starch $(26,27,28)$ from glucose-1-phosphate. More recent findings have shown that synthesis of sucrose $(31,21,4,22)$ and of starch $(34,35,1,8)$ are mediated by UDPG or ADPG. It is believed that the Keq of UDPG-sucrose transglycosylase favors sucrose synthesis, but only when acting as an independent entity (2):

$$
\text { UDPG + fructose } \rightarrow \text { Sucrose + UDP }
$$

When coupled with starch formation, thermodynamics then favors polysaccharide synthesis $\left(\Delta \mathrm{F}^{\circ}=-2300\right.$ cal. $)$ :

$$
\text { Sucrose } \stackrel{\text { (ADP or UDP) }}{\longrightarrow}\left[\begin{array}{c}
\text { ADPG } \\
\text { or } \\
\text { UDPG }
\end{array}\right] \rightarrow \text { Starch }
$$

The sucrose-starch interconversion is strongly implied by mill problems such as starch-retarded filtration and crystallization rates of cane juices $(21,42)$. Very large quantities of starch have been encountered with the Uba variety in South Africa (25). Work in Puerto Rico also supports some 
type of sucrose-starch interconversion $(5,6)$, and amylase suppression has been correlated with rapid sucrose formation $(3,19)$. In another study abnormally high sucrose synthesis was induced by withholding $N, P, K$ or $\mathrm{Ca}$, and in each instance a vastly retarded amylase action accompanied the sucrose increases (19). Our thinking has been that amylase should alter any direct equilibiium between sucrose and polysaccharide synthesis. However, subsequent observations have not consistently verified this theory, indicating that direct interconversion is an oversimplification of an extremely complicated series of reactions $(5,6)$.

To some degree the sucrose-starch problem in sugarcane is accountable to the unusual action pattern of cane amylase, and its apparent "working partnership" with invertase. Cane-leaf amylase can apparently act as a glucosidase, cleaving single glucose units from various polysaccharides and oligosaccharides (17). When combined with invertase the glucose product is immediately converted to a disaccharide believed to be maltose. It is felt that cane amylase should not be regarded as acting upon storage starch, such as the starch granules of the cereals and the potato, but rather as an instantaneous converter of newly formed, short-chain polysaccharides. Again, the reaction must be quite overwhelming since starch is virtually undetectable in most modern cane varieties. Thus amylase action can be visualized as a delicately balanced mechanism which, on one hand, is needed in sufficient strength to prevent accumulation of excess polysaccharide, and which when severely suppressed can permit a shift in the starch-sucrose equilibrium in favor of sucrose. It is also suspected that cane amylase can attack the glucosidic linkages in raffinose and sucrose. In this instance a suppression of amylase might lead to increased sucrose via a slackening of sucrose inversion. This reaction should not be confused with those of the true cane invertases, which are unable to act against polysaccharides and are not found in the leaf (18).

The present study underscores two theories with regard to cane amylase: 1, Amylase content is a varietal feature. The differences between P.R. 980 and P.R. 1059 are, regardless of temperature, incontestable. 2, Amylase behavior is so greatly altered by temperature that, in view of its intimate roles in sucrose-starch interconversion, it must be considered a major factor in varietal sensitivity to the cold stimulus.

It is interesting to speculate that the actual mechanism of cold sensitivity is one of inhibitor synthesis rather than enzyme formation or activation. Lozano and Bonner (32) found that while potato tubers retain starch above $10^{\circ} \mathrm{C}$. they lose starch between 0 and $10^{\circ} \mathrm{C}$, and that a natural inhibitor of starch phosphorylase disappears during the cold exposure. Furthermore, increased starch breakdown was accompanied by more rapid sucrose synthesis. Our own work has shown that cane phosphorylase 
becomes inactive following dialysis, but that starch synthetase then becomes quite active (8). Thus an endogenous inhibitor is strongly implied.

The cold-increased capacity of P.R. 1059 to accumulate sucrose in immature storage tissue is apparently a direct function of invertase synthesis. As is seen from table 4, very little invertase was detected in the P.R. 1059 storage tissue following cool treatment. Interest is immediately drawn to the mechanism of invertase synthesis which is clearly temperature-sensitive, and which has been noted in cane hybrids by workers in Australia ( 80 ). Yet the mechanism itself must be dominated by variety. It is concluded that invertase synthesis, like that of amylase, is a temperature-sensitive but variety-controlled mechanism. Conversely, it must be responsible at least to some degree for determining which varieties shall respond to cold stimuli by sucrose accumulation.

\section{SUMMARY}

Initial sugarcane studies were completed with controlled-climate facilities at Río Piedras, Puerto Rico. The phytotron is designed to provide a broad range of controlled temperature, light and humidity. Employing the sand-culture technique, a high-tonnage variety (P.R. 980) and a highsucrose variety (P.R. 1059) was exposed to continually warm and cool temperatures for 10 weeks. Treatments were initiated when the plants were 12 weeks of age. The objective was to evaluate growth, sugar production, and enzymology of the two varieties at 55 to $60^{\circ} \mathrm{F}$., and at $80^{\circ}$ to $85^{\circ} \mathrm{F}$. The following results were obtained:

1. Fresh-weight measurements indicated a more rapid growth rate by plants exposed to warm temperature. Growth by P.R. 980 exceeded that of P.R. 1059. Cool temperature induced a general stockiness and equal growth of both varieties. The warm treatment resulted in a spindly condition in both varieties and frequent lodging for P.R. 980 .

2. Both sucrose and total ketose production was much higher at 80$85^{\circ} \mathrm{F}$. than at $55-60^{\circ} \mathrm{F}$. in each variety, as evidenced by leaf-sugar values. At both temperature ranges P.R. 1059 was clearly superior to P.R. 980 as a sucrose producer. Fructose content was extremely low under warm conditions, suggesting a rapid utilization of inverted sucrose for growth.

3. Sugar content of storage tissues varied greatly in response to both temperature and variety treatments. Although sucrose was rapidly synthesized at 80 to $85^{\circ} \mathrm{F}$. neither variety was able to accumulate the sugar in immature storage tissue at that temperature range. At 55 to $60^{\circ}$ F., P.R. 1059 accumulated high sucrose in the immature storage tissue but P.R. 980 failed to do so. Brix and polarization data showed that in millable stalk tissues P.R. 980 responded far more readily than P.R. 1059 to the 
cold treatment. It is suggested that high-tonnage varieties such as P.R. 980 may require a cold stimulus for maximum sucrose accumulation, whereas the cool exposure may not be essential for high sucrose producers such as P.R. 1059.

4. Numerous enzyme variations were encountered with leaf and meristem preparations. The greatest differences were found in leaves where varietal effects outweighed those of temperature. All leaf enzymes measured, including phosphatase, ATP-ase, amylase, peroxidase, and tyrosinase, were significantly less active in P.R. 980 than in P.R. 1059. Low temperature further lowered the enzyme values. It is believed that insufficient enzyme potential was available in cold-treated P.R. 980 to acheive either normal growth or sugar synthesis.

5. Only traces of invertase were detected in meristem of P.R. 1059 exposed to cold temperature. This accounts for high sucrose accumulation in that tissue while supporting the concept of a temperature-sensitive, invertase-synthesizing mechanism.

6. Amylase content varied greatly in response to temperature and varietal treatments. Amylase activity was about three times greater in P.R. 1059 than in P.R. 980. Within variety treatments, amylase values were about two times greater in plants exposed to $80-85^{\circ} \mathrm{F}$., as compared with $55-60^{\circ} \mathrm{F}$. Amylase roles in determining varietal and temperature control over sucrose level is discussed from the standpoint of sucrose and starch interconversion.

\section{RESUMEN}

Se completaron estudios preliminares con caña de azúcar utilizando las instalaciones para el control de la temperatura que existen en la Estación en Río Piedras, Puerto Rico. El fitotrón está diseñdo para permitir una amplia variación de temperatura, luz y humedad reguladas. Mediante la técnica del cultivo en arena, se expusieron dos variedades de caña, una de tonelaje alto (la P.R. 980) y otra de porcentaje de azúcar alto (la P.R. 1059), a temperaturas constantemente tibias y frías por espacio de 10 semanas. Los tratamientos se comenzaron cuando las plantas tenían 12 semanas de edad. El objetivo era evaluar el crecimiento, el rendimiento de azúcar y la enzimología de las dos variedades a $55-60^{\circ} \mathrm{F}$. y a $80-85^{\circ} \mathrm{F}$. Se obtuvieron los siguientes resultados:

1. Los pesos húmedos revelaron un ritmo de crecimiento mayor de las plantas expuestas a una temperatura tibia. La variedad P.R. 980 superó en crecimiento a la P.R. 1059. La temperature fría ocasionó un crecimiento igual en las dos variedades y ambas desarrollaron cañas generalmente más gruesas, mientras que la temperatura tibia indujo el desarrollo de 
cañas delgadas en ambas variedades, y causó el encamado frecuente de la P.R. 980.

2. La producción de sacarosa y cetosas totales fue mucho mayor en cada variedad a $80-85^{\circ} \mathrm{F}$. que a $55-60^{\circ} \mathrm{F}$. como lo demuestran los valores del contenido de azúcar en la hoja. Bajo ambas regímenes de temperatura la P.R. 1059 demostró obvia superioridad a la P.R. 980 en cuanto a rendimiento de sacarosa. Bajo condiciones de tibieza, el contenido de fructosa fue extremadamente bajo, lo cual sugiere que la sacarosa invertida se utiliza rápidamente para el crecimiento.

3. La temperatura y la variedad se manifestaron en una gran variación en el contenido de azúcar en los tejidos reservantes. Aunque la sacarosa se sintetizó rápidamente a $80-85^{\circ} \mathrm{F}$., ninguna de las variedades pudo acumular azúcar en el tejido reservante tierno a esa temperatura. A $55-60^{\circ} \mathrm{F}$., la P.R. 1059 acumuló mucha sacarosa en su tejido reservante tierno, pero no así la P.R. 980. El índice de refracción y la polarización indicaron que las cañas de la variedad P.R. 980 listas para la molienda reaccionaron con más rapidez al tratamiento frío que las de la P.R. 1059. Esto sugiere que las variedades de tonelaje alto como la P.R. 980 acaso requieran condiciones frías a manera de estímulo para alcanzar una acumulación máxima de sacarosa, mientras que el frío puede que no sea esencial para las variedades de alto rendimiento de sacarosa, como la P.R. 1059.

4. Se encontró una gran variación en la acción de las enzimas contenidas en las. preparaciones foliares y meristemáticas. Las mayores diferencias se hallaron en aquellas hojas en que los efectos causados por las diferencias de variedad sobrepasaron a los de la temperatura. Al evaluarse, todas las enzimas de la hoja incluyendo la fosfatasa, la ATP-asa, la amilasa, la peroxidasa y la tirosinasa revelaron ser significativamente menos activas en la P.R. 980 que en la P.R. 1059. Una temperatura baja disminuyó aún más los valores de las enzimas. Se cree que el potencial enzimático de la P.R. 980 que se expuso al frío no bast6 para alcanzar un crecimiento o una sintesis normal de azúcar.

5. En el meristemo de la P.R. 1059 que se expuso a una temperatura baja solo se revelaron rastros de invertasa. Esto explica la alta acumulación de sacarosa en dicho tejido, y a la vez da apoyo al concepto de que existe un mecanismo para la sintesis de la invertasa que es sensitivo a los cambios de temperatura.

6. El contenido de amilasa varió grandemente como resultado de los cambios en la temperatura y del factor variedad. La actividad de la amilasa fue aproximadamente tres veces mayor en la P.R. 1059 que en la P.R. 980. En una misma variedad, los valores de la amilasa fueron casi dos veces mayores en las plantas expuestas a temperaturas de $80-85^{\circ} \mathrm{F}$., comparadas 
con las expuestas a $55-60^{\circ} \mathrm{F}$. Se discuten las funciones de la amilasa al determinar hasta donde el control de las variedades y de la temperatura afecta el nivel de sacarosa, desde el punto de vista de la interconversión de la sacarosa y el almidón.

\section{LITERATURE CITED}

1. Akazawa, T., Minamikawa, T., and Murata, T., Enzymatic mechanism of starch synthesis in ripening rice grains, Plant Physiol. 39: 371-8, 1964.

2. Akazawa, T., Starch, inulin, and other reserve polysaccharides, Chapter 12 of: Plant Biochemistry, edited by Bonner, J., and Varner, J. E., Academic Press, New York, N. Y., 1964, p. 282.

3. Alexander, A. G., Sucrose-enzyme relationships in immature sugarcane as affected by varying levels of nitrate and potassium supplied in sand culture, J. Agr. Univ. P.R., 48 (3): 165-231, 1964.

4. - The biosynthesis of Sucrose in sugarcane, J. Agr. Univ. P.R. 48 (4): 26583, 1964.

5. - Physiological studies of enzymes catalyzing the synthesis and hydrolysis of sucrose, starch, and phosphorylated hexose in sugarcane, J. Agr. Univ. P.R. 49 (1): 60-75, 1965.

6. - Behavior of enzymes governing starch-and sucrose-forming pathways in two sugarcane varieties supplied with variable nitrate and phosphate in sand culture, J. Agr. Univ. P.R. 49 (2): 153-75, 1965.

7. - Induction of varying sugar levels in leaves of immature sugarcane by use of acid phosphatase inhibitors, J. Agr. Univ. P.R. 49 (1): 35-59, 1965.

8. - The biosynthesis of starch in sugarcane, Proc. Intnl. Soc. Sugarcane Technol., XII Ann. Cong., San Juan, P.R., 625-38, 1967.

9. - Effects of tungsten and molybdenum on sucrose content and hydrolytic enzymes of immature sugarcane, J. Agr. Univ. P.R. 49 (4): 429-42, 1965.

10. - Hydrolytic proteins of sugarcane: The Q enzyme, J. Agr. Univ. P.R. 49 (2): 176-203, 1965.

11. - Hydrolytic proteins of sugarcane: The acid phosphatases, J. Agr. Univ. P.R. 49 (2): 204-28, 1965.

12. - Hydrolytic proteins of sugarcane: The acid invertases, J. Agr. Univ. P.R. 49 (3): 287-307, 1965.

13. - Hydrolytic proteins of sugarcane: Amylase, J. Agr. Univ. P.R. 49 (3): 308-24, 1965.

14. - The oxidizing enzymes of sugarcane: Peroxidase, J. Agr. Univ. P.R. 60 (1): 36-52, 1966.

15. - The oxidizing enzymes of sugarcane: Tyrosinase (polyphenol oxidase), $J$. Agr. Univ. P.R. 50 (2): 113-30, 1966.

16. - The oxidizing enzymes of sugarcane: Cytochrome $\mathbf{C}$ oxidase, J. Agr. Univ. P.R. 60 (2): $131-45,1966$.

17. - The action pattern of sugarcane-leaf amylase, J. Agr. Univ. P.R. 51 (2): 154-66, 1967.

18. - Comparative studies of sugarcane and yeast invertase, J. Agr. Univ. P.R. (In press).

19. - High sucrose and abnormal enzyme activity as a function of nutritional stress in sugarcane, J. Agr. Univ. P.R. 61 (4): 325-33, 1967.

20. - Interrelationships of gibberellic acid and nitrate in sugar production and enzyme activity of sugarcane, $J$. Agr. Univ. P.R. 62 (1): 19-28, 1968. 
21. Balch, R. T., Further notes on starch in Louisiana canes, juices and raw sugars, Sugar J. 15: 11-15, 1953.

22. Cardini, C. E., Leloir, L. F., and Chiriboga, J., The biosynthesis of sucrose, $J$. Biol. Chem. 214: 149-55, 1955.

23. Coleman, R. E., and Nickell, L. G., Stability of the flowering stimulus in isolated stem tips of sugarcane, Nalure 201 (4922): 941-2, 1964.

24. Dugger, W. M., and Humphreys, T. E., Influence of boron on enzymatic reactions associated with biosynthesis of sucrose, Plant Physiol. s5: 523-30, 1960.

25. Feulherade, L., Starch in Uba juices, South Africa Sugar J. 18: 305-9, 1929.

26. Green, D. E., and Stumpf, P. K., Starch phosphorylase of potato, J. Biol. Chem. 124: 355-66, 1942.

27. Hans, C. S., The breakdown and synthesis of starch by an enzyme system from pea seeds, Proc. Roy. Soc. (London), B 128: 421-50, 1940.

28. - Reversible formation of starch from glucose-1-phosphate catalyzed by potato phosphorylase, Proc. Roy. Soc. (London), B 129: 174-208, 1940.

29. Hassid, W. Z., Doudoroff, M., Barker, H. A., and Dore, W. H., Isolation and structure of an enzymatically synthesized crystalline disaccharide d-glucosided-ketoxyloside, J. Amer. Chem. Soc. 68 (1): 465-7, 1946.

30. Hatch, M. D., and Glasziou, K. T., Sugar accumulation cycle in sugarcane. II. Relationship of invertase activity to sugar content and growth rate in storage tissue of plants grown in controlled environments, Plant Physiol. $\$ 8(3): 344-8$, 1963.

31. Leloir, L. F., and Cardini, C. E., The biosynthesis of sucrose phosphate, J. Biol. Chem. 214: 157-65, 1955.

32. Lozano, B. A., and Bonner, J., Experiments on sucrose formation by potato tubers as influenced by temperature, Plant Physiol. 24: 720-9, 1949.

33. Lugo López, M. A., and Capo, B. G., The effect of weather and climate on the sucrose content of sugarcane, J. Agr. Univ. P.R. 38 (4): 149-69, 1954.

34. Recondo, E., and Leloir, L. F., Adenosine diphosphate glucose and starch synthesis, Biochem. Biophys. Res. Commun. 6: 85-8, 1961.

35. Recondo, E., Dankert, M., and Leloir, L. F., Isolation of adenosine diphosphate D-glucose from corn grains. Biochem. Biophys. Res. Commun. 12: 204-7, 1963.

36. Robinson, P., Report on gibberellic acid field trials on sugarcane 1963-1964, Personal exchange of data between Dr. Robinson, C.S.R. Australia, and Dr. G. Samuels, Estación Experimental, Río Piedras, P.R.

37. Roe, J. R., A colorimetric method for the determination of fructose in blood and urine, J. Biol. Chem. 107: 15-22, 1934.

38. Samuels, G., Sugarcane ripening and maturity: Theoretical background, Proc. of the Annual Congress of The Assoc. of Sugar Technologists of Puerto Rico, Nov. 1965.

39. Sumner, J. B., and Somers, G. F., Chemistry and Methods of Enzymes, Academic Press Inc., New York, N.Y., 1953, p. 116.

40. Sutherland, E. W., Cori, C. F., Haynes, R., and Olsen, N. S., Purification of the hyperglycemic-glycogenolytic factor from insulin and from gastric mucosa, J. Biol. Chem. 180: 825-37, 1949.

41. Went, F. W., Temperature. In: Encyclopedia of Plant Physiology. W. Ruhland, ed., Springer-Verlag. Berlin, Germany, 16: 1-22, 1961.

42. Wood, G. H., Some factors influencing starch in sugarcane, Proc. South African Sug. Technol. Assn. p. 123, April 1962. 